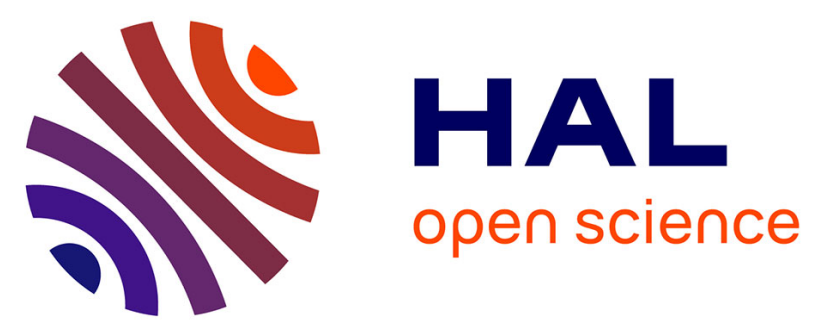

\title{
Out-of-phase Late Pleistocene glacial maxima in the Western Alps reflect past changes in North Atlantic atmospheric circulation
}

Natacha Gribenski, Pierre G Valla, Frank Preusser, Thibault Roattino, Christian Crouzet, Jean-François Buoncristiani

\section{To cite this version:}

Natacha Gribenski, Pierre G Valla, Frank Preusser, Thibault Roattino, Christian Crouzet, et al.. Outof-phase Late Pleistocene glacial maxima in the Western Alps reflect past changes in North Atlantic atmospheric circulation. Geology, 2021, 49 (9), pp.1096-1101. 10.1130/G48688.1 . hal-03388270

\section{HAL Id: hal-03388270 \\ https://hal.science/hal-03388270}

Submitted on 20 Oct 2021

HAL is a multi-disciplinary open access archive for the deposit and dissemination of scientific research documents, whether they are published or not. The documents may come from teaching and research institutions in France or abroad, or from public or private research centers.
L'archive ouverte pluridisciplinaire HAL, est destinée au dépôt et à la diffusion de documents scientifiques de niveau recherche, publiés ou non, émanant des établissements d'enseignement et de recherche français ou étrangers, des laboratoires publics ou privés. 


\section{Out-of-phase Late Pleistocene glacial maxima in the Western}

2 Alps reflect past changes in North Atlantic atmospheric

\section{3 circulation}

4 Natacha Gribenski ${ }^{1}$, Pierre G. Valla ${ }^{2,1}$, Frank Preusser $^{3}$, Thibault Roattino $^{2}$, Christian

5 Crouzet $^{2}$, Jean-François Buoncristiani ${ }^{4}$

$6 \quad{ }^{1}$ Institute of Geological Sciences, University of Bern, Bern, Switzerland

$7 \quad$ ISTerre, Université Grenoble Alpes, Université Savoie Mont Blanc, CNRS, IRD, IFSTAR,

8 Grenoble, France

$9{ }^{3}$ Institute of Earth and Environmental Sciences, University of Freiburg, Freiburg, Germany

$10{ }^{4}$ UMR 6282 Biogéosciences, CNRS/Univ Bourgogne Franche-Comté, Dijon, France

13 ABSTRACT

14 Paleoglacier reconstructions in the northern and southern forelands of the European Alps indicate 15 a synchronous Late Pleistocene glacial maximum during Marine Isotope Stage (MIS) 2, in phase 16 with global ice volume records. However, strong controversy remains in the western foreland,

17 where scarce and indirect dating as well as modelling studies suggest out-of-phase glacial 18 maxima with the rest of the Alps. New luminescence dating brings the first direct Late 19 Pleistocene glacial chronology for the western Alpine foreland and reveals two major glacier 20 advances of similar maximum extent, at ca. 75-60 and ca. 40-30 ka, coinciding with MIS 4 and 21 late MIS 3. We propose that asynchrony in glacial maxima between the western and the 22 northern/southern Alpine forelands results from a progressive spatial reorganization of the 
23 atmospheric circulation over the North Atlantic, in response to Northern Hemisphere ice-sheet

24 fluctuations. While such feedback mechanism has emerged from general circulation models, our

25 Late Pleistocene paleoglacial reconstruction permits to track the spatio-temporal evolution of 26 moisture advection patterns over Western Europe.

\section{INTRODUCTION}

29 Ice-core and marine paleoclimate archives show two main periods of global temperature minima 30 during the Late Pleistocene (LP; the last ca. $130 \mathrm{kyr}$; NGRIP, 2004), coinciding with Marine

31 Isotope Stage (MIS) 4 and 2 (71-57 and 29-14 ka; Lisiecki and Raymo, 2005). Marine records

32 indicate the main peak in global ice volume, also largely reported from terrestrial glacier 33 archives, during the Last Glacial Maximum (LGM; ca. 27-19 ka; Clark et al., 2009). However,

34 local glacial maxima well before the LGM are increasingly recorded in polar and mountain 35 regions (Hughes et al., 2013; Batchelor et al., 2019). The emerging picture of variable ice 36 expansion in both time and space likely reflects the regional effect of dynamic atmospheric 37 circulations (Löfverström et al., 2014). Accurate glacial reconstructions across the globe are thus 38 crucial to constrain past atmospheric circulation and paleo-precipitation patterns (e.g. 39 Kuhlemann et al., 2008).

40 In the European Alps, major LP glaciations are recorded in prominent morainic lobes spreading 41 over several tens of kilometers in the forelands (Ehlers et al., 2011; Fig. 1). In the northern and 42 southern forelands, synchronous LP glacial maxima at ca. 26-23 ka have been documented 43 (Monegato et al., 2017). On the western side, the most extensive LP glaciation occurred in the 44 Lyon area (Fig. 1a), where an ice lobe draining the Arve (western Mont Blanc massif) and the 45 Isere catchments developed $\sim 50 \mathrm{~km}$ westward into the piedmont (Coutterand et al., 2009). In 46 contrast to other Alpine forelands, scarce and indirect radiocarbon data in this area suggest older 
47 LP ice-maxima than the global LGM (Mandier et al., 2003). Such asynchronous paleoglacial

48 activity is supported by numerical simulations suggesting transgressive glacier dynamics across

49 the Alps, with the observed maximum ice extent in the Western Alps only reached when

50 considering paleo-precipitation partitioning or older (i.e. MIS 4) glacier advance (Becker et al.,

51 2016; Seguinot et al., 2018).

52 To further examine the hypothesis of asynchronous paleoglacial dynamics across the Alps, a

53 robust chronology in the Western Alps is now critical. Radiocarbon and cosmogenic nuclide

54 exposure dating are challenging in this area due to the scarcity of organic material incorporated

55 within glacial deposits and in-place moraine boulders, respectively. Here, we present the first

56 direct chronology of LP ice-maximum extent in the Lyon area, using optically stimulated

57 luminescence (OSL) dating of glaciofluvial sediments. These results not only enlighten the

58 debate around the paleoglacial history of the Western Alps, but also have major implications in

59 terms of past atmospheric circulation over the North Atlantic and Western Europe.

60

\section{SETTING AND METHODS}

62 Two main moraine complexes, separated by $\sim 25 \mathrm{~km}$, define the Middle ( $\geq$ MIS 6; External

63 Moraine Complex, EMC) and Late (Internal Moraine Complex, IMC) Pleistocene ice-maximum

64 extents in the Lyon area (Buoncristiani and Campy, 2011; Fig. 1a). While the EMC presents

65 discrete, highly-degraded and discontinuous moraine crests, the IMC is characterized by a series

66 of well-defined frontal moraine ridges (Fig. 1a).

67 Glaciofluvial valleys (i.e. inactive today) expand over several tens of kilometers westward from

68 the IMC (Fig. 1a), containing large sediment infills organized in step terraces. In the western and

69 southern sectors, the IMC lays on a bedrock topographic step rising abruptly $>200 \mathrm{~m}$ above the

70 present-day lowland (Fig. 1b). This topographic configuration allows to unambiguously relate 
71 glaciofluvial sediment deposition and terraces formation to major ice-extent periods (i.e. IMC

72 ridges), when ice and meltwater could overtop this escarpment. Previous geomorphic and

73 sedimentological studies identified at least three main terrace levels which, from high (T1/T2) to

74 low (T4), directly connect to external (M2) to internal (M4) moraine ridges from the IMC

75 (Mandier, 1988; Roattino et al., 2021; Fig 1a), and thus were formed by aggradation during

76 periods of glacial advances (Marren, 2005). Typical coarse braided-river facies exposed along

77 the terraces do not permit to argue for major discontinuity in terrace construction. Discrete

78 outermost IMC ridges (M1) are visible only in the NW sector, suggesting an additional glacial

79 stage hardly preserved through subsequent glacial periods (overridden moraine patterns; Fig.

80 DR1 in the GSA Data repository), and with possible remnants in the east and south sectors of the

81 IMC indistinguishable from the M2 deposits. In the absence of direct numerical dating, it

82 remains challenging to quantitatively relate the observed glacial stages to distinct glaciations or

83 short-term glacier oscillations.

84 We targeted the three main terrace levels (T1/T2 to T4; Fig. 1a), with six samples collected from

85 well-sorted sand lenses exposed in quarry sections (Table 1, Appendix DR1). Samples were

86 taken as close as possible to the terrace surfaces to capture the last depositional period related to

87 a glacial stage. Two additional samples were collected from a glaciofluvial unit underlying till

88 from an M1 ridge in the NW sector (PIZ site; Fig. 1a, Table 1), providing maximum age

89 constraints of the LP outermost ice extent.

90 Luminescence signals and equivalent doses $\left(D_{e}\right)$ were measured from quartz (green OSL) and

91 feldspar (infra-red stimulation at $50^{\circ} \mathrm{C}$ and $225^{\circ} \mathrm{C}, \mathrm{IR}_{50}$ and post-IRIR 225 ) single grains (SG, 200-

$92 \quad 250 \mu \mathrm{m}$ fraction). Methodological details are given in the GSA Data repository (DRII). Total

93 burial dose since sample deposition was determined using the Central Age Model (CAM $\left.D_{e}\right)$ or

94 Finite Mixture statistical model $\left(\mathrm{FMM} D_{e}\right)$ in case of partial bleaching diagnosis (Galbraith and 
95 Roberts, 2012). Feldspar burial doses were corrected for anomalous fading (20-30\% increase,

96 Table DR3) and final ages were calculated using sample-specific dose rate (2-3 Gy $\mathrm{ka}^{-1}$ range,

97 Tables DR4,5), derived from element concentrations measured by laboratory gamma

98 spectrometry.

99

100

101

102

103

104

105

106

107

108

109

110

111

112

113

114

115

116

117

118

\section{RESULTS}

SG quartz OSL data could only be acquired for three samples (EYP1, OYT1, SPC5; Table 1), for which $\sim 2 \%$ of measured grains emit a suitable luminescence signal. This is consistent with low luminescence sensitivity typically observed in quartz from crystalline bedrock and/or with limited transport (Sakawuchi et al., 2011). All eight samples reveal good feldspar luminescence characteristics (20-40\% suitable grains).

SG quartz $D_{e}$ distributions exhibit normal-like to moderately-skewed shapes, while SG feldspar $D_{e}$ distributions are widely spread, asymmetric and multimodal, with a significant fraction of saturated grain for post-IRIR 225 (Figs. 2b, DR6,7). In addition, feldspar CAM $D_{e}$ are significantly larger $(>50 \%)$ than for quartz. Both complex SG $D_{e}$ distributions and CAM $D_{e}$ differences between feldspar and quartz are strong indicators for limited pre-depositional exposure to light, typical for proximal glaciofluvial sediments (Duller, 2006). Partial bleaching, leading to age overestimate, was diagnosed for most of the samples and especially for feldspar signals. We thus applied statistical techniques (i.e. FMM model) to extract $D_{e}$ from the best-bleached grain subpopulations, giving more accurate age determination. For final age calculation, quartz OSL and feldspar $\mathrm{IR}_{50}$ were selected, based on their best bleaching potential.

Quartz OSL and feldspar $\mathrm{IR}_{50}$ ages obtained from the highest terrace in the central part of the study area (T1/T2: SPC5; Fig. 1a) and from the intermediate (T3: ART2, OYT1, EYP1) to lower (T4: ART1) terrace levels overlap between ca. 42 and 39 ka (Fig. 3b; Table 1). Where both 
119

120

121

122

123

124

125

126

127

128

129

130

131

132

133

134

135

136

137

138

139

140

141

142

available, quartz OSL and feldspar $\mathrm{IR}_{50}$ ages agree within uncertainties, bringing further confidence in the statistical treatment applied to complex feldspar $\operatorname{IR}_{50} D_{e}$ distributions. The southern highest terrace level (PEN1) resulted in a distinctly older $\mathrm{IR}_{50}$ age of $63.0 \pm 11.4 \mathrm{ka}$, coinciding with two $\mathrm{IR}_{50}$ ages of $60.8 \pm 12.3$ and $76.4 \pm 15.1 \mathrm{ka}$ obtained for the glaciofluvial unit underlying the north-western M1 ridge (PIZ1 and PIZ2; Table 1).

\section{DISCUSSION}

Luminescence dating indicates two periods of glaciofluvial aggradation beyond the IMC: between ca. 60-75 ka and ca. 30-40 ka, coinciding with MIS 4 and late MIS 3 respectively. This result strongly suggests that western Alpine glaciers reached the IMC at least twice during the LP, with similar maximum ice-extent configuration. The main terrace-moraine sequence (T2/T3/T4 - M2/M3/M4) observed in the area would hence result from glacier margin oscillations during a single glaciation period (i.e. late MIS 3), whereas scarce and outer remnant deposits (T1 - M1) were preserved from an earlier MIS 4 glacial maxima.

Our new MIS 4 chronology further corroborates earlier studies based on scarce chronological data in the Swiss Alpine foreland (Gaar et al., 2019 and references therein), and in the nearby Pyrenees (Delmas et al., 2011), as well as results from numerical simulations (Fig. 3a; Seguinot et al., 2018), all of which proposed significant glaciations in the Western European mountain ranges at that time. The late MIS 3 glaciation clearly predates the last glacial maxima recorded in the northern and southern Alpine forelands during MIS 2 (Monegato et al., 2017). However, an extended MIS 3 ice advance has been suggested in the southwestern Alpine foreland (e.g. IvyOchs et al., 2018), while valleys and forelands in the northern and central Alps were reported to be ice-free before $30 \mathrm{ka}$ (Preusser et al., 2011; Barret et al., 2017). The absence of MIS 2 ages in our dataset, in particular for the lowest (T4) terrace level (ART 1, 33.8 $\pm 7.3 \mathrm{ka}$ ), suggests that no 
glacier advance reached the IMC after late MIS 3. This is further supported by radiocarbon ages (Fig. 1a; Mandier et al., 2003) of ca. 27 to $>35 \mathrm{ka}$ from a paleosol above till (i.e. minimum ages) in the NW sector of the IMC (Balan) and of 28-30 ka from glacio-lacustrine deposits 10-20 km upstream of the IMC (Moras and Malville), which suggest shorter glacier extent in the area during MIS 2. It is unlikely that the time lag (ca. $10 \mathrm{kyr}$ ) observed for the last major advance between the Lyon and northern/southern central Alpine forelands is caused by methodological uncertainties, as the applied dating approaches have shown age consistency on such timescales in similar glacial settings (e.g. Smedley et al., 2016; Gribenski et al., 2018).

In addition to multiple and similar LP glacial maxima in the western Alpine foreland predating the global LGM, our data indicates spatially and temporarily variable paleo-glacier extent patterns across the European Alps, which likely reflect differential precipitation distribution combined with periods of global cooling. In contrast to the modern dominance of north-west atmospheric circulation, it has been proposed that south-dominated moisture advection prevailed across the Alps during the LGM (Florineth and Schlüchter, 2000; Luetscher et al., 2015; Monegato et al., 2017). The southward latitudinal shift of the North Atlantic storm track, as far as $40^{\circ} \mathrm{N}$, was forced by the development of large ice masses and sea ice in the North Hemisphere (NH; Fig. 3c), as indicated by atmospheric general circulation models (e.g. Hofer et al., 2012). The extensive MIS 4 glaciation in the western Alpine foreland coincides with a major cooling period observed at the global and regional scales (NGRIP, 2004; Helmens, 2014; Moseley et al., 2020). Further elaborating on the above circulation model, we propose that the moderate expansion of the NH ice sheets during MIS 4, as indicated by deep-marine sediment records (Lisiecki and Raymo, 2005), could have similarly initiated a more discrete storm-track migration southward (Löfverström et al., 2014). Moisture was thus dominantly brought from the west and promoted high precipitation in the west-facing massifs of the Western Alps, enabling favorable 
167 conditions (i.e. wet and cold) for large piedmont glaciers. While cold MIS 4 conditions are 168 expected across the entire Alps, limited precipitation in the Central and Eastern Alps may have 169 resulted in more restricted ice extents in the main northern/southern central forelands, with 170 glacial deposits likely eroded during the greater MIS 2 extent.

171 During MIS 3, global ice records indicate a decrease of temperatures already at 40 ka before 172 reaching minima at 25-20 ka (NGRIP, 2004). Few existing long-term regional records suggest 173 similar trends in SW Europe, even with a potentially earlier cooling onset at $45 \mathrm{ka}$ (Moreno et 174 al., 2014; Moseley et al., 2020). After significant shrinkage during early MIS 3, NH ice sheets 175 started to expand again from ca. $40 \mathrm{ka}$ (Batchelor et al., 2019). Similar to our proposed MIS 4 176 scenario, dominant western moisture advection would have been maintained throughout mid/late 177 MIS 3 with a progressive southward shift of the polar storm track, again favoring glacier extent 178 in the Western Alps. This configuration changed with the ongoing growth of NH ice sheets 179 towards the LGM, which further pushed the polar storm track southward and lead shortly after $18030 \mathrm{ka}$ to the main southerly moisture advection over the European Alps (Luetscher et al., 2015). 181 Interestingly, the lacustrine record at Les Echets (Fig. 1a) also points towards a major change in 182 lake productivity at ca. $28-30 \mathrm{ka}$, with a climatic transition from highly-oscillating to relatively 183 stable, dry and cold conditions (Veres et al., 2009). We propose that this change in atmospheric 184 circulation resulted in significant moisture decrease over the Western Alps, while enabling maximum glacier extent in the southern and northern Alpine forelands during MIS 2.

\section{CONCLUSIONS}

188 Our luminescence chronology constitutes the first direct evidence of two major Late Pleistocene 189 glaciations reaching similar maximum extents in the western Alpine foreland, during MIS 4 (76$60 \mathrm{ka})$ and late MIS 3 (42-29 ka). These multiple and early glacial maxima revealed in the 
191 western foreland contrast with MIS 2 maximum ice extent recorded in the northern and southern 192 sides of the European Alps, in phase with the global LGM. Such spatial variability in glacier

193 fluctuations has been observed elsewhere around the globe and likely translates swaying 194 atmospheric circulation and precipitation partitioning during the last glacial cycle. We propose 195 that such configuration may be related to the gradual migration of the polar storm track, forced 196 by the progressive development of NH ice sheets. This study further highlights the importance of 197 regional paleo-glacier reconstructions and numerical chronologies for quantifying past changes 198 in atmospheric circulation patterns.

199

\section{ACKNOWLEDGMENTS}

201 This work was supported by the SNSF (PP00P2_170559), INSU and USMB (AAP Montagne).

202 We thank Gachet TP, Eiffage, Cemex Granulat Rhône Méditerranée, Nord Isère Matériaux and 203 Vicat Granulat for providing access to gravel pits. We thank the four anonymous reviewers for 204 their valuable suggestions.

205 206

\section{REFERENCES}

208 Barrett, S.J., Starnberger, R., Tjallingii, R., Brauer, A., and Spötl, C., 2017, The sedimentary 209 history of the inner-alpine Inn Valley (Austria): extending the Baumkirchen type section further back in time with new drilling: Journal of Quaternary Science, v. 32, p. 63-79, https://doi.org/10.1002/jqs.2924

212 Batchelor, C.L., Margold, M., Krapp, M., Murton, D.K., Dalton, A.S., Stokes, C.R., Murton, 213 J.B., and Manica, A., 2019, The configuration of Northern Hemisphere ice sheets through 
the Quaternary: Nature Communications, v. 10, p. 3713, https://doi.org/10.1038/s41467$019-11601-2$

Becker, P., Seguinot, J., Jouvet, G., and Funk, M., 2016, Last Glacial Maximum precipitation pattern in the Alps inferred from glacier modelling: Geographica Helvetica, v. 71, p. 173-187, https://doi.org/10.5194/gh-71-173-2016

Buoncristiani, J.-F. and Campy, M., 2011, Quaternary glaciations in the French Alps and Jura: Developments in Quaternary Sciences, v. 15, p. 117-126, https://doi.org/10.1016/B978$0-444-53447-7.00010-6$

Clark, P.U., Dyke, A.S., Shakun, J.D., Carlson, A.E., Clark, J., Wohlfarth, B., Mitrovica, J.X., Hostetler, S.W. and McCabe, A.M., 2009, The Last Glacial Maximum: Science, v. 325, p. 710-714, https://doi.org/10.1126/science. 1172873

Coutterand, S., Schoeneich, P., Nicoud, G., 2009, Le lobe glaciaire lyonnais au maximum würmien : glacier du Rhône ou/et glaciers savoyard?. Philip Deline, Ludovic Ravanel. Neige et glace de montagne : Reconstitution, dynamique, pratiques, Collection EDYTEM - Cahiers de Géographie, v. 8, p. 11-22, <halshs-00389085>

Delmas, M., Calvet, M., Gunnell, Y., Braucher, and R., Bourlès, D., 2011, Paleogeography and 10Be exposure-age chronology of Middle and Late Pleistocene glacier systems in the northern Pyrenees: implications for reconstructing regional paleoclimates: Palaeogeography, Palaeoclimatology, Palaeoecology, v. 305, p.109-122, https://doi.org/10.1016/j.palaeo.2011.02.025

Duller, G.A.T., 2006, Single grain optical dating of glacigenic deposits: Quaternary Geochronology, v. 1, p. 296-304, https://doi.org/10.1016/j.quageo.2006.05.018 
Ehlers, J., Gibbard, P.L., and Hughes, P.D., eds., 2011, Quaternary Glaciations - Extent and Chronology: A Closer Look: Developments in Quaternary Science, v. 15. Elsevier, Amsterdam,1108 p.

Florineth, D., and Schlüchter, C., 2000, Alpine evidence for atmospheric circulation patterns in Europe during the Last Glacial Maximum: Quaternary Research, v. 54, p. 295-308, https://doi.org/ 10.1006/qres.2000.2169

Gaar, D., Graf, H.R., and Preusser, F., 2019, New chronological constraints on the timing of Late Pleistocene glacier advances in northern Switzerland, E \& G Quaternary Science Journal, v. 68, p. 53-73, https://doi.org/10.5194/egqsj-68-53-2019

Galbraith, R.F., and Roberts, R.G., 2012, Statistical aspects of equivalent dose and error calculation and display in OSL dating: An overview and some recommendations: Quaternary Geochronology, v. 11, p.1-27, https://doi.org/10.1016/j.quageo.2012.04.020

Gribenski, N., Jansson, K.N., Preusser, F., Harbor, J.M., Stroeven, A.P., Trauerstein, M., Blomdin, R., Heyman, J., Caffee, M.W., Lifton, N., and Zhang, W., 2018, Re-evaluation of MIS 3 glaciation using cosmogenic radionuclide and single grain luminescence ages, Kanas Valley, Chinese Altai: Journal of Quaternary Science, v. 33, p. 55-67, https://doi.org/10.1002/jqs.2998

Helmens, K.F., 2014, The Last Interglaciale Glacial cycle (MIS 5-2) re-examined based on long proxy records from central and northern Europe: Quaternary Science Reviews, v. 86, p. 115-143, http://dx.doi.org/10.1016/j.quascirev.2013.12.012

Hofer, D., Raible, C.C., Merz, N., Dehnert, A., and Kuhlemann, J., 2012, Simulated winter circulation types in the North Atlantic and European region for preindustrial and glacial conditions: Geophysical Research Letters, v. 39, L15805, http://dx.doi.org/10.1029/2012GL052296 
Hughes, P.D., Gibbard, P.L., Ehlers, J., 2013, Timing of glaciation during the last glacial cycle: evaluating the concept of a global 'Last Glacial Maximum' (LGM): Earth-Science Reviews, v. 125, p. 171-198, https://doi.org/10.1016/j.earscirev.2013.07.003

Ivy-Ochs, S., Lucchesi, S., Baggio, P., Fioraso, G., Gianotti, F., Monegati, G., Graf, A.A., Akçar, N., Christl, M., Carraro, F., Gabrialla Forno, M., amd Schlüchter, C., 2018, New geomorphological and chronological constraints for glacial deposits in the Rivoli Avigliana end-moraine system and the lower Susa Valley (Western Alps, NW Italy): Journal of Quaternary Science, v. 33, p. 550-562, https://doi.org/10.1002/jqs.3034

Kuhlemann, J., Rohling, E.J., Krumrei, I., Kubik, P., Ivy-Ochs, S. and Kucera, M., 2008, Regional synthesis of Mediterranean atmospheric circulation during the Last Glacial Maximum: Science, v. 321, p. 1338-1340, https://doi.org/10.1126/science.1157638

Lisiecki, L.E. and Raymo, M.E., 2005, A Pliocene-Pleistocene stack of 57 globally distributed benthic $\quad{ }^{18} \mathrm{O}$ records: Paleoceanography, $\quad$ v. $20, \quad$ p. $1-17$, https://doi.org/10.1029/2004PA001071

Löfverström, M., Caballero, R., Nilsson, J., and Kleman, J., 2014, Evolution of the large-scale atmospheric circulation in response to changing ice sheets over the last glacial cycle: Climate of the Past, v. 10, p. 1453-1471, https://doi.org/10.5194/cp-10-1453-2014

Luetscher, M., Boch, R., Sodemann, H., Spötl, C., Cheng, H., Edwards, R. L., Frisia, S., Hof, F., and Müller, W., 2015, North Atlantic storm track changes during the Last Glacial Maximum recorded by Alpine speleothems: Nature Communications, v. 6, p. 6344, https://doi.org/10.1038/ncomms7344

Mandier, P., 1988, Le relief de la moyenne vallée du Rhône au Tertiaire et au Quaternaire: essai de synthèse paléogéographique. Bureau de Recherches Géologiques et Minières, Orléans, 865 pp. 
Mandier, P., Evin, J., Argant, J., and Petiot, R., 2003, Chronostratigraphie des accumulations würmiennes dans la moyenne vallée du Rhône. L'apport des dates radiocarbones: Quaternaire, v. 14/2, p. 113-127, https://doi.org/10.3406/quate.2003.1735

Marren, P., 2005, Magnitude and frequency in proglacial rivers: a geomorphological and sedimentological perspective: Earth Science Reviews, v. 70, p. 203-251, https://doi.org/10.1016/j.earscirev.2004.12.002

Moreno, A., Svensson, A., Brooks, S.J., Connor, S., Engels, S., Fletcher, W., Genty, D., Heiri, O., Labuhn, I., Persiou, A., Peyron, O., Sadori, L., Valero-Garces, B., Wulf, S., and Zanchetta, G., 2014, A compilation of Western European terrestrial records 60-8 ka BP: towards an understanding of latitudinal climatic gradients: Quaternary Science Reviews, v. 106, p. 167-185. https://doi.org/10.1016/j.quascirev.2014.06.030

Monegato, G., Scardia, G., Hajdas, I., Rizzini, F., and Piccin, A., 2017, The Alpine LGM in the boreal ice-sheets game: Nature Scientific reports, v. 7, p. 2078, https://doi.org/10.1038/s41598-017-02148-7

Moseley, G.E., Spötl, C., Brandstätter, S., Erhardt, T., Luetscher, M., and Edwards, R.L., 2020, NALPS19: sub-orbital-scale climate variability recorded in northern Alpine speleothems during the last glacial period: Climate of the Past, v. 16, p. 29-50, https://doi.org/10.5194/cp-16-29-2020

NGRIP members, 2004, High-resolution record of Northern Hemisphere climate extending into the last interglacial period: Nature, v. 43, p. 147-151, https://doi.org/10.1038/nature02805

Preusser, F., Graf, H. R., Keller, O., Krayss, E., and Schlüchter, C., 2011, Quaternary glaciation history of northern Switzerland: E\&G Quaternary Science Journal, v. 60, p. 21, https://doi.org/10.3285/eg.60.2-3.06 
Roattino, T., Crouzet, C., Buoncristiani, J-F., Tissoux, H., 2021, Geometry of glaciofluvial deposits and dynamics of the Lyonnais lobe ice front during the last glacial period (France, Northern Alps): Earth Science Bulletin BSGF, Accepted

Sakawuchi, A.O., Blair, M.W., DeWitt, R., Faleiros, F.M., Hyppolito, T., and Guedes, C.C.F., 2011, Thermal history versus sedimentary history: OSL sensitivity of quartz grains extracted from rocks and sediments: Quaternary Geochronology, v. 6, p. 261-272, https://doi.org/10.1016/j.quageo.2010.11.002

Seguinot, J., Ivy-Ochs, S., Jouvet, G., Huss, M., Funk, M., and Preusser, F., 2018, Modelling last glacial cycle ice dynamics in the Alps: The Cryosphere, v. 12, p. 3265-3285, https://doi.org/10.5194/tc-12-3265

Smedley, R.K., Glasser, N.F., and Duller, G.A.T., 2016, Luminescence dating of glacial advances at Lago Buenos Aires ( $\left.46^{\circ} \mathrm{S}\right)$, Patagonia: Quaternary Science Reviews, v. 134, p. 59-73, http://dx.doi.org/10.1016/j.quascirev.2015.12.010

Veres, D., Lallier-Vergès, E., Wohlfarth, B., Lacourse, T., Kéravis, D., Björck, S., Preusser, F., Andrieu-Ponel, V., and Ampel, L., 2009, Climate-driven changes in lake conditions during late MIS 3 and MIS 2: a high-resolution geochemical record from Les Echets, France: Boreas, v. 38, p. 230-243, https://doi.org/10.1111/j.1502-3885.2008.00066.x

Wirsig, C., Zasadni, J., Christl, M., Akçar, N., and Ivy-Ochs, S., 2016, Dating the onset of LGM ice surface lowering in the High Alps: Quaternary Science Reviews, v. 143, p. 37-50, https://doi.org/10.1016/j.quascirev.2016.05.001

\section{TABLE \& FIGURE CAPTIONS}

Table 1: Sample locations and luminescence ages. 
331 Figure 1: (a) Glacial geomorphology of the study area (Mandier, 1988; Roattino et al., 2021).

332 Inset: geomorphic limits of the LP ice maximum in the Alps (Ehlers et al., 2011) with main

333 LGM ice flows (light blue arrows; Wirsig et al., 2016), and location of the study area (black box)

334 with main ice-drainage catchments (dark blue limit, AR: Arve, IS: Isère). (b) Longitudinal

335 topographic profile (LP1) showing bedrock escarpement underlying the IMC ridges and

336 downstream glaciofluvial sediments (undifferentiated), when the glacier reached its LP

337 maximum extent. (c) Topographic cross-profile (ART site; CP1) showing the main three terrace

338 levels. The bedrock/sediment contact is extrapolated from borehole data (Roattino et al., 2021).

339

340 Figure 2: Quartz normal-like and feldspar (no fading correction) complex single-grain burial age

341 distributions for a representative sample (SPC5). Consistent quartz and feldspar sample burial 342 ages are obtained using the CAM and FMM models respectively, based on the different partial 343 bleaching diagnosis.

345 Figure 3: (a) Late Pleistocene Northern Alpine speleothems $\delta^{18} \mathrm{O}$ (purple; Moseley et al., 2020) 346 and global marine sediments $\delta^{18} \mathrm{O}$ (grey curve with MIS in shaded bars; Lisiecki and Raymo, 347 2005) records, with modelled Alpine ice volume (blue, GRIP paleoclimate forcing; Seguinot et 348 al., 2018). (b) Luminescence ages showing two main groups around MIS 4 (green) and late MIS 3493 (orange), consistent with existing radiocarbon ages from the NW sector (green) and upstream 350 (red) of the IMC (Mandier et al., 2003). (c) Conceptual sketch illustrating the southward shift of 351 the North Atlantic storm track forced by gradual NH ice sheet growth (LGM extent in blue), with 352 impact on the paleo-atmospheric circulation (coloured arrows). 
$354{ }^{1}$ GSA Data Repository item 201Xxxx, [Details of samples' geomorphological and 355 sedimentological context, and luminescence dating], is available online at 356 www.geosociety.org/pubs/ft20XX.htm, or on request from editing@geosociety.org. 
Figure 2

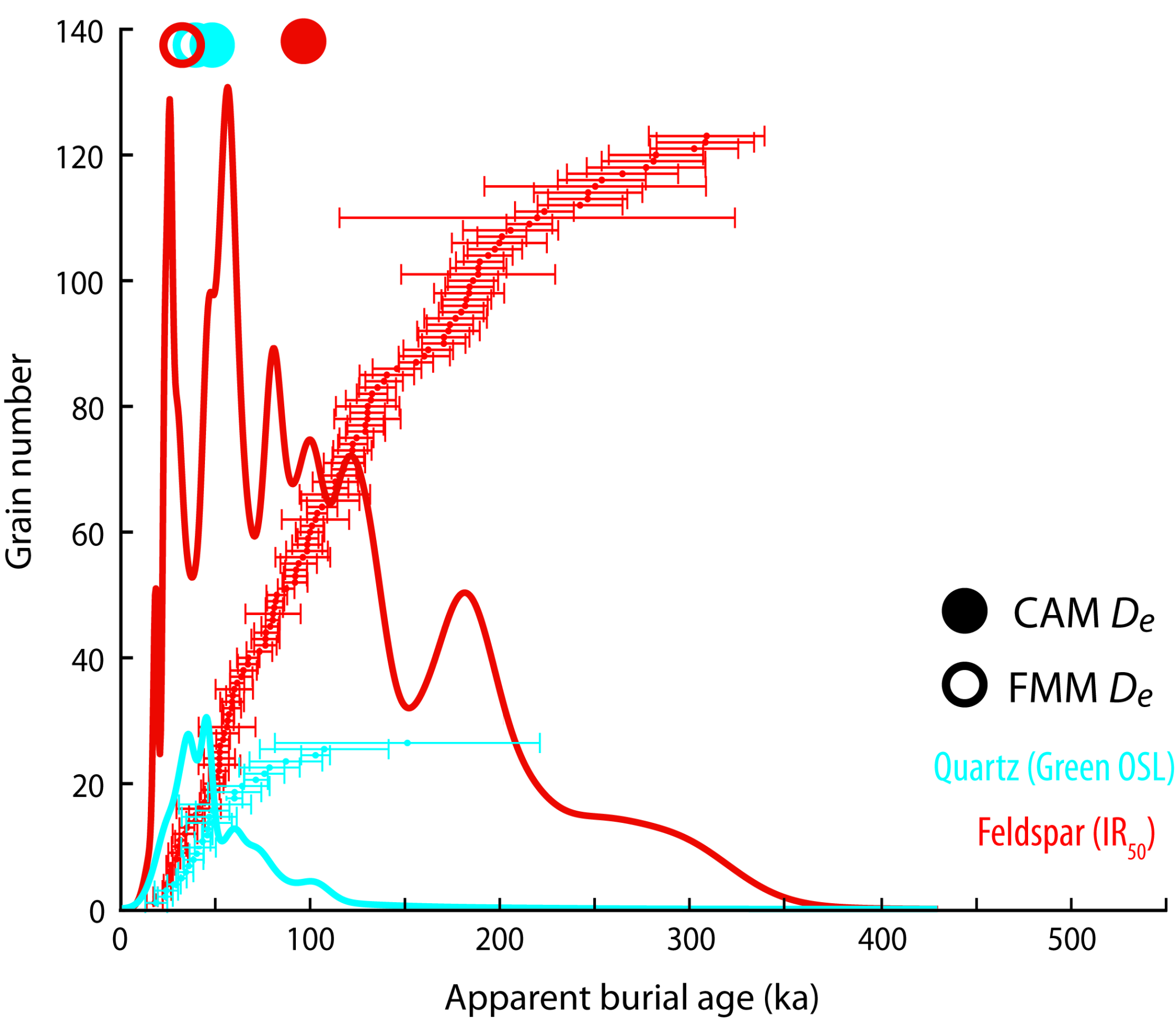


a)

Marine Isotope Stages (MIS)

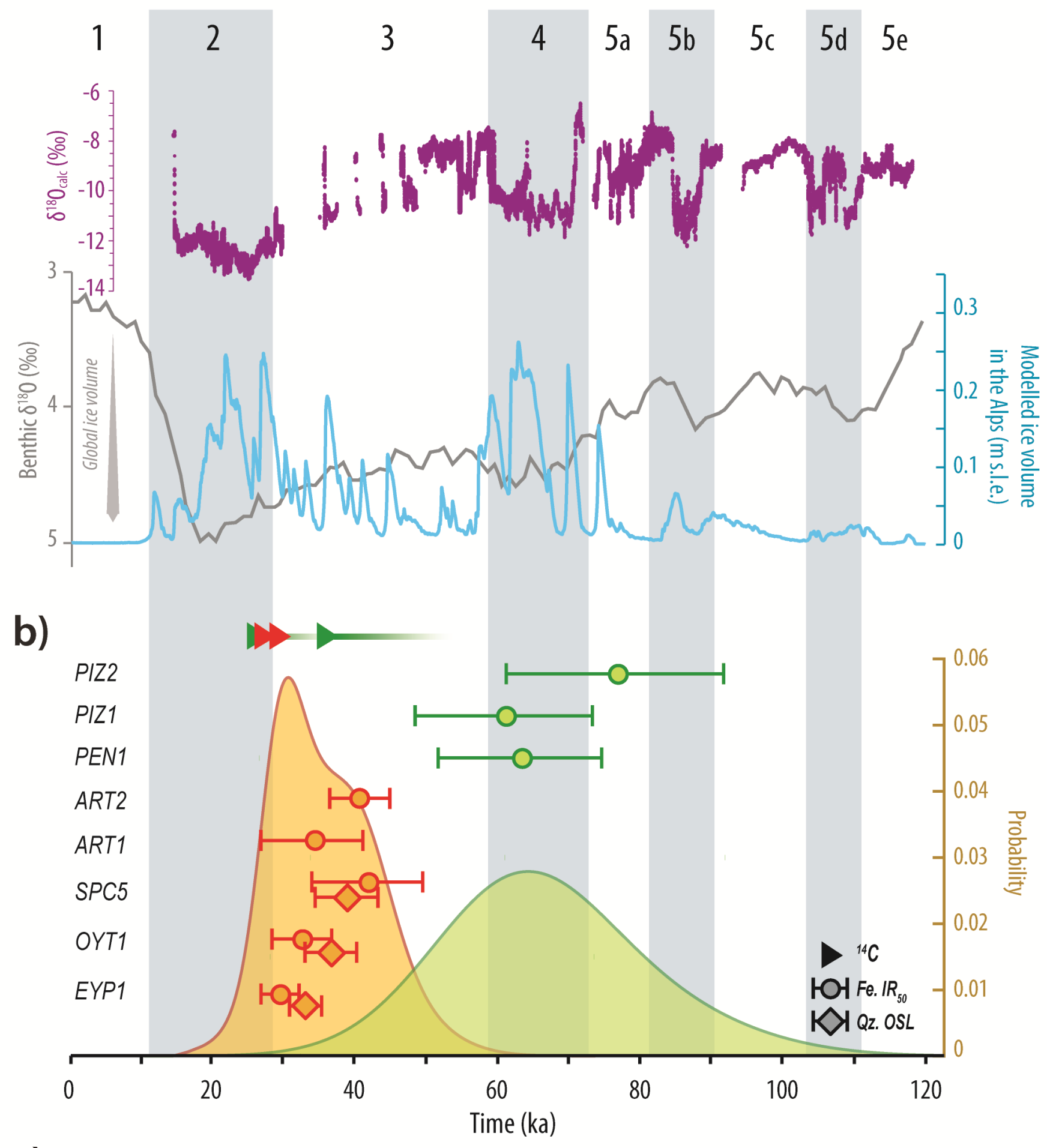

c)

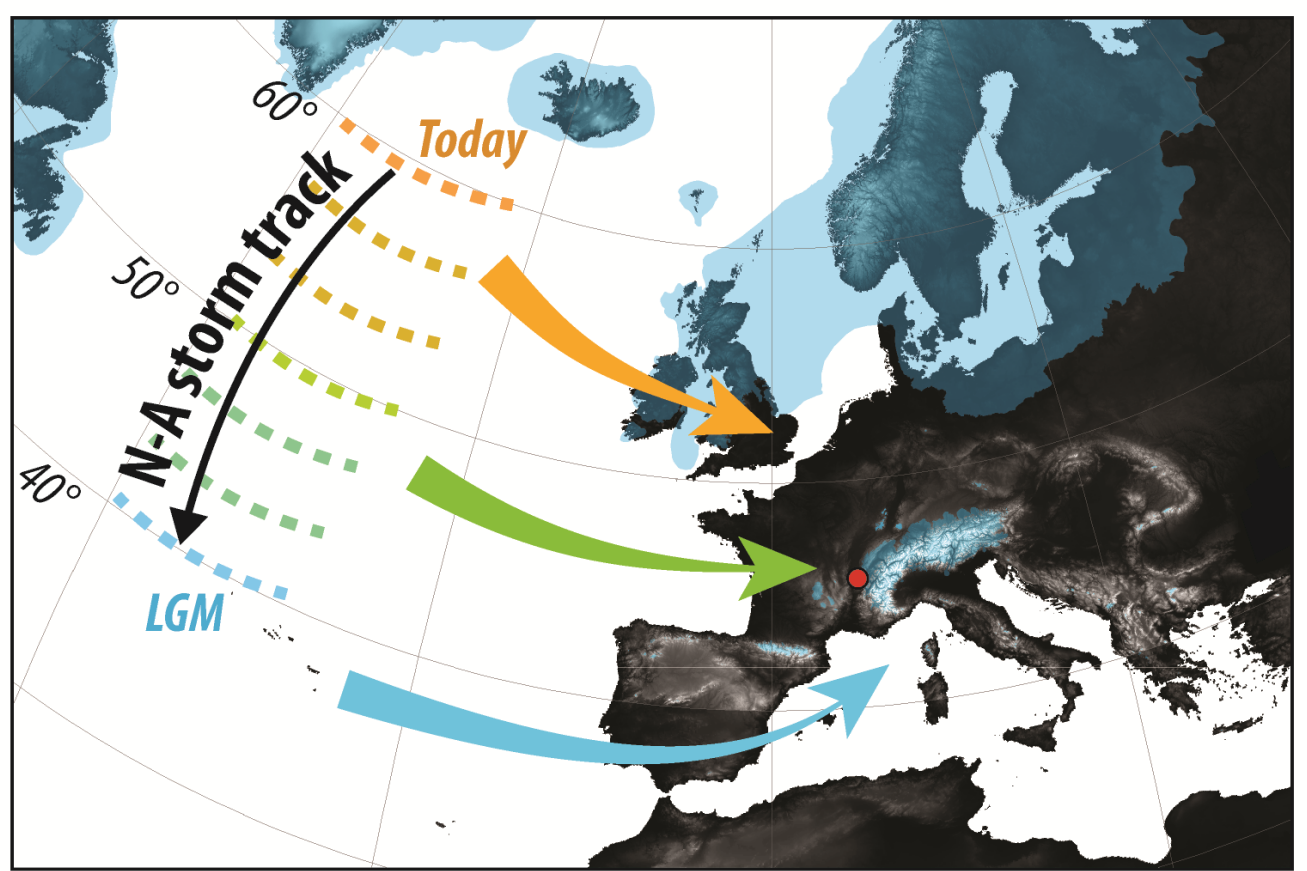


Gribenski et al., 2021—Table

Table 1. Sample locations and luminescence ages

\begin{tabular}{ccccccc}
\hline $\begin{array}{c}\text { Sample } \\
\text { ID }\end{array}$ & $\begin{array}{c}\text { Lat./ Long. } \\
\left({ }^{\circ} \mathbf{N} /{ }^{\circ} \mathbf{E}\right)\end{array}$ & $\begin{array}{c}\text { Elevation } \\
(\mathbf{m} \text { a.s.l. })\end{array}$ & $\begin{array}{c}\text { Depth } \\
(\mathbf{m} \text { below } \\
\text { surface })\end{array}$ & $\begin{array}{c}\text { Geomorphic } \\
\text { unit }\end{array}$ & $\begin{array}{c}\text { Quartz } \\
(\mathbf{O S L}) \text { age } \\
(\mathbf{k a})\end{array}$ & $\begin{array}{c}\text { Feldspar } \\
\left(\mathbf{I R}_{\mathbf{5 0}}\right) \mathbf{a g e} \\
(\mathbf{k a})\end{array}$ \\
\hline EYP1 & $45.496 / 5.009$ & 262 & 5 & $\mathrm{~T} 3$ & $32.9 \pm 2.3$ & $29.4 \pm 2.8$ \\
OYT1 & $45.575 / 5.030$ & 265 & 3.2 & $\mathrm{~T} 3$ & $36.4 \pm 3.8$ & $32.4 \pm 4.3$ \\
SPC5 & $45.666 / 5.015$ & 250 & 5 & T1/T2 & $38.6 \pm 4.5$ & $41.6 \pm 7.9$ \\
ART1 & $45.537 / 5.182$ & 430 & 3 & T4 & - & $33.8 \pm 7.3$ \\
ART2 & $45.536 / 5.182$ & 420 & 12 & T3 or T4 & - & $40.6 \pm 4.2$ \\
PEN1 & $45.363 / 5.186$ & 313 & 12 & T1/T2 & - & $63.0 \pm 11.4$ \\
PIZ1 & $45.876 / 5.088$ & 250 & 13 & underlying M1 & - & $60.8 \pm 12.3$ \\
PIZ2 & $45.876 / 5.088$ & 256 & 2 & underlying M1 & - & $76.4 \pm 15.1$ \\
\hline
\end{tabular}

